\title{
Healy attacks NASA's claims; bad news for research budgets
}

Washington. The fierce competition for funds in the 1993 federal budgets now moving through the US Congress has shattered, possibly forever, the idea of a united front for science. The most visible sign of that splintering came last week when Bernadine Healy, director of the National Institutes of Health (NIH), rebuked Daniel Goldin, head of the National Aeronautics and Space Administration (NASA), for arguing that the proposed space station would be a boon to biomedical research. Her letter was dated one day before the US House of Representatives voted to spend $\$ 1.73$ billion next year on Space Station Freedom, and opponents of the space station cited it unsuccessfully during the debate before Goldin had even read it.

It is probably no coincidence that this internecine warfare between two officials of the Bush administration came at the same time as the House, in separate budget votes last week, warned NIH and the National Science Foundation (NSF) to prepare for the worst. For NIH, a budget that rises by 3 per cent not only falls short of the 5 per cent increase sought by the president but also ends a tradition in which Congress has added substantially to whatever the president requested. For NSF, a research budget that stays flat in 1993 dashes its request for a 13 per cent increase and makes a mockery of the promise by the president to double the foundation's budget in five years.

The House bill at least gives NIH \$297 million more than it now has, although the increase falls $\$ 147$ million short of the president's request and is less than is required to maintain the current level of new grants. Two days later, the Senate committee that oversees NSF's budget gave NSF some $\$ 20$ million less to spend on research in 1993 than in 1992, at the same time increasing spending for science edu- cation by $\$ 45$ million and creating a $\$ 55$ million programme to retrain engineers now working on military projects. The levels for NSF are expected to be ratified by the entire Senate this week; however, action on the NIH budget is not scheduled until the middle of September. In each case, differences between the two houses must be ironed out in conference. opportunities. And they do not want to be used as the justification for a project they oppose.

Two days before the vote in the House, an article critical of the space station appeared on the opinion pages of The Washington Post. Coauthored by biologist Maxine Singer, the president of the Carnegie Institution and a former NIH researcher, and Donald Brown, president of the American Society for Cell Biology, the article predicted that "the biology done on the space station will [likely] turn out to be a whopping and very expensive bore". The next day, Goldin replied in print that "space-based research in the life sciences and biotechnology will revolutionize our way of life in the 21 st century", and he thapsodized about "the possibilities for life science research with a full-time, stateof-the-art laboratory aboard Space Station Freedom".

On the same day that Goldin's article appeared, Healy wrote to him that she was "particularly dis-

As disappointing as the NSF votes were, they were overshadowed by the attacks from the biomedical community on NASA for its repeated claims of potential breakthroughs from research in space in the fight against a host of diseases, including cancer and AIDS. For more than a year, the American Physical Society has led a campaign to defeat the $\$ 40$-billion space station, arguing that its scientific contribution will be minimal and that the money could be much better spent on Earth-bound research.

The argument has so far failed to sway Congress: on 29 July the House voted 237:181 to reject an amendment to kill the space station, a margin that differed little from the 240:173 vote last year on the same amendment. But NASA's decision to highlight the life sciences has enraged biomedical researchers already upset that NIH's budget, at $\$ 9$ billion, is not growing fast enough to keep up with the scientific turbed by the implication that $\mathrm{NIH}$ views future space experiments as critical to the overall success of biomedical research". She reminded him that she had told Congress last autumn that "it is unclear precisely how the unique space environment might be used to advance research on conventional health problems". And she warned Goldin that his comments, if not revised, could do "a serious disservice ... by the creation of unrealistic expectations and overpromise".

Healy's comments are unlikely to alter the NASA administrator's rhetoric, nor derail the space station; their real audience is the biomedical community, and the letter shows them that Healy is on their side. But the verbal battles, waged in public, also demonstrate the difficulty of maintaining a united front when times are tough. When budgets are at stake, the first rule is every discipline for itself.

Jeffrey Mervis 